\title{
PERBEDAAN KADAR ASAM URAT PADA PENDERITA HIPERTENSI DENGAN DIABETES MELITUS TIPE 2 DAN TANPA DIABETES MELITUS TIPE 2
}

\author{
THE DIFFERENCES OF URIC ACID LEVELS IN HYPERTENSIVE PATIENTS WITH \\ TYPE 2 DIABETES MELLITUS AND WITHOUT TYPE 2 DIABETES MELLITUS
}

\author{
Yudrik Maulana, Iin Novita N M, Indriyati Oktaviano R \\ Fakultas Kedokteran Universitas Muhammadiyah Surakarta \\ Korespondensi: dr. Iin Novita NM, SpPD, Email: iin_novita@ums.ac.id
}

\begin{abstract}
ABSTRAK
Peningkatan kadar asam urat memegang peranan penting pada terjadinya morbiditas pasien hipertensi. Diabetes mellitus (DM) merupakan komorbid yang sering ditemukan pasien hipertensi. Tujuan penelitian ini adalah untuk mengetahui perbedaan kadar asam urat pada penderita hipertensi dengan DM tipe 2 dan tanpa DM tipe 2 di Rumah Sakit Umum Daerah Dr. Sayidiman Magetan. Penelitiian ini merupakan melakukan penelitian analitik observasional dengan rancangan penelitian cross sectional. Subjek penelitian adalah penderita hipertensi dengan DM tipe 2 dan tanpa DM tipe 2 di RSUD Dr. Sayidiman. Teknik pengambilan sampel dilakukan secara consecutive sampling. Data diperoleh dari data rekam medik pasien periode Januari 2012 hingga Juni 2015. Penelitian ini menggunakan 54 sampel, terdiri dari 27 pasien pada kelompok hipertensi dengan DM tipe 2 dan 27 pasien pada kelompok hipertensi tanpa DM tipe 2. Pada uji t, didapatkan bahwa rerata kadar asam urat pada

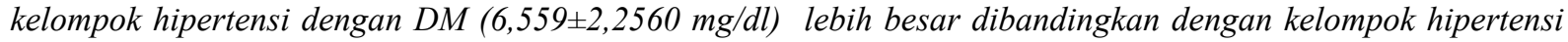
tanpa DM tipe $2(4,922 \pm 1.3051 \mathrm{mg} / \mathrm{dl})$ secara signifikan $(p=0,002)$. Kesimpulan: Rerata kadar asam urat pada kelompok hipertensi dengan DM tipe 2 lebih besar dibandingkan dengan kelompok hipertensi tanpa DM tipe 2.
\end{abstract}

Kata kunci: Kadar asam urat, Hipertensi, DM tipe 2

\begin{abstract}
The increasement levels of uric acid plays an important role in the morbidity of patients with hypertension. Diabetes mellitus (DM) is a common comorbid hypertensive patients. The aim of this study to know the distinction of uric acid levels in hypertensive patients with type 2 diabetes mellitus and without diabetes mellitus type 2 in $X$ hospitals of Magetan. Researchers conducted an observational analytic research with cross sectional study design. The research subjects were hypertensive patients with type 2 diabetes mellitus and without tipe 2 diabetes mellitus in $X$ hospitals. The sampling technique performed in consecutive sampling. Data were obtained from medical records of patients from January 2012 to June 2015.This study used 54 samples, consists of 27 patients in the group of hypertension with type 2 diabetes mellitus and 27 patients in the group of hypertensive without type 2 diabetes mellitus. The mean of levels of uric acid in hypertension with type 2 diabetes mellitus group $(6.559 \pm 2.2560 \mathrm{mg} / \mathrm{dl})$ were higher than hypertension without type 2 diabetes mellitus group $(4.922 \pm 1.3051 \mathrm{mg} /$ dl) by t-test $(p=0.002)$. Conclusions: The mean of levels of uric acid in hypertension with type 2 diabetes mellitus were higher than hypertension without type 2 diabetes mellitus
\end{abstract}

Keywords: Uric acid level, Hypertension, Type 2 diabetes mellitus

\section{PENDAHULUAN}

Hipertensi merupakan penyebab kematian nomor satu di dunia, disusul merokok kemudian dislipidemia (Yugiantoro, 2014). Data World Health Organization (WHO) pada tahun 2013 menunjukkan bahwa sekitar $40 \%$ penduduk dunia usia 25 tahun ke atas menderita hipertensi.
Badan kesehatan dunia menyebutkan penderita hipertensi di dunia mengalami peningkatan dari 600 juta penderita pada tahun 1980 menjadi 1 miliar penderita pada tahun 2008 .

Data yang dihimpun oleh Kementrian Kesehatan menyebutkan jumlah penderita hipertensi di Indonesia pada tahun 2013 sebanyak 
25,8\% (65 juta jiwa). Di Provinsi Jawa Timur sendiri pada tahun 2012 hipertensi merupakan penyakit dengan pasien rawat jalan terbanyak di RSUD bertipe B, C, dan D, dengan total keseluruhan penderita rawat jalan sebanyak 226.668 (Dinas Kesehatan Provinsi Jawa Timur, 2013).

Adapun berdasarkan survei awal yang dilakukan oleh peneliti di Rumah Sakit Dr. Sayidiman Magetan, diperoleh data pada 1 Januari sampai 31 Desember 2014 terdapat 1.488 pasien rawat inap dengan diagnosis hipertensi, sedangkan pada pasien rawat jalan terdapat 8.558 kunjungan pasien hipertensi.

Hipertensi merupakan faktor risiko utama untuk kematian dan kecacatan, terutama pada orang dengan diabetes melitus (DM). Menurut studi yang dilakukan di Kanada tingkat kematian penduduk Kanada yang menderita hipertensi dan DM 2,5 kali lebih tinggi dari pada penduduk Kanada yang hanya menderita hipertensi atau DM saja (Campbell et al., 2011).

Hiperurisemia adalah salah satu komorbid hipertensi yang meningkatkan mortalitas dan morbiditas penyakit kardiovaskuler (Weir et al., 2003). Sedangkan salah satu faktor yang dapat meningkatkan angka kejadian hiperurisemia adalah kondisi resistensi insulin dalam hal ini salah satunya adalah DM tipe 2 (Abreu et al., 2011).

Perbedaan kadar asam urat pada penderita hipertensi dengan DM dan tanpa DM sendiri masih kontroversial. Studi yang dilakukan Taniguchi et al (2001) pada journal of hypertension menunjukan tidak adanya hubungan antara kadar asam urat dengan DM. Di sisi lain, beberapa studi menunjukan adanya hubungan yang positif antara kadar asam urat dengan DM (Liong et al., 2008; Kodama et al., 2009; Kramer et al., 2009). Di Indonesia sendiri diperkirakan prevalensi DM mencapai 21,3 juta orang pada tahun 2030 (Wild et al., 2004).

Berdasarkan uraian di atas diketahui bahwa perbedaan kadar asam urat pada penderita hipertensi dengan DM dan tanpa DM masih kontroversial. Oleh karena itu, dilakukannya penelitian ini untuk mengetahui apakah memang terdapat perbedaan kadar asam urat pada penderita hipertensi dengan DM dan penderita hipertensi tanpa DM khususnya pada DM tipe 2.

\section{METODE}

Desain penelitian ini menggunakan metode analitik observasional dengan rancangan penelitian cross-sectional. Penelitian ini dilakukan di Rumah Sakit Umum Daerah Dr. Sayidiman Magetan pada bulan Desember 2015. Populasi pada penelitian ini yaitu pasien hipertensi dengan DM tipe 2 dan tanpa DM tipe 2 yang menjalani perawatan di Rumah Sakit Umum Daerah Dr. Sayidiman Magetan periode Januari 2012 sampai Juni 2015.

Sampel dalam penelitian ini adalah pasien Rumah Sakit Umum Daerah Dr. Sayidiman Magetan yang memenuhi kriteria inklusi. Pengambilan sampel dilakukan secara nonprobability sampling dengan menggunakan teknik consecutive sampling. Caranya adalah setiap anggota populasi sumber yang memenuhi kriteria restriksi dipilih sebagai sampel sampai jumlah sampel yang diperlukan terpenuhi.Data yang diambil dalam penelitian ini merupakan data rekam medis penderita yang terdaftar pada periode Januari 2012 sampai Juni 2015.

Berdasarkan rumus besar sampel untuk studi analitis numerik tidak berpasangan didapatkan besar minimal masing-masing kelompok adalah 25 subjek. Kriteria sampel yang memenuhi syarat adalah pasien hipertensi dengan DM tipe 2 dan tanpa DM tipe 2 yang kadar asam uratnya tercatat dalam rekam medis di RSUD Dr. Sayidiman Magetan, usia 20-70 tahun, dan pasien dengan jenis kelamin laki-laki maupun perempuan. Adapun kriteria sampel yang tidak memenuhi syarat untuk dijadikan sampel penelitian adalah pasien dengan data rekam medis yang tidak lengkap, memiliki riwayat penggunaan allopurinol dan diuretik sebelumnya, dan pasien yang memiliki riwayat menderita gagal ginjal,anemia hemolitik, dan kanker.

Variabel bebas dalam penelitian ini adalah pasien hipertensi dengan DM tipe 2 dan tanpa DM tipe 2. Tekanan sistolik, diastolik, kadar gula darah sewaktu, dan gula darah puasa didapatkan berdasarkan hasil data rekam medis dan didiagnosis oleh dokter spesialis penyakit dalam Rumah Sakit Umum Daerah Dr. Sayidiman Magetan. Variabel terikat dalam penelitian ini adalah kadar asam urat yang didapatkan berdasarkan data rekam medis Rumah Sakit Umum Daerah Dr. Sayidiman Magetan

Data yang sudah terkumpul akan dianalisa 
menggunakan program SPSS. Normalitas sebaran data pada penelitian ini menggunakan uji Shapiro-Wilk karena besar sampel masingmasing kelompok kurang dari 50.Uji hipotesis pada penelitian ini menggunakan uji $\mathrm{T}$ tidak berpasangan jika data normal, jika data tidak normal maka akan digunakan uji Mann Whitney.

\section{HASIL DAN PEMBAHASAN}

Penelitian ini dilaksanakan di Rumah Sakit Umum Daerah Dr. Sayidiman Magetan pada bulan Desember 2015. Subjek dalam penelitian ini adalah pasien hipertensi dengan DM tipe 2 dan tanpa DM tipe 2 yang menjalani perawatan di Rumah Sakit Umum Daerah Dr. Sayidiman Magetan yang memenuhi kriteria restriksi penelitian. Data yang diambil dalam penelitian ini merupakan data rekam medis penderita yang terdaftar pada periode Januari 2012 sampai Juni 2015. Data keseluruhan yang diperoleh berjumlah 200 rekam medis, tetapi yang memenuhi kriteria restriksi berjumlah 54 rekam medis, yang terdiri dari 27 rekam medis pasien hipertensi dengan DM tipe 2 dan 27 rekam medis pasien hipertensi tanpa DM tipe 2.

1. Karakteristik Subjek Penelitian

Tabel 1. Distribusi Subjek Penelitian

\begin{tabular}{|c|c|c|c|}
\hline Karakteristik & Kelompok & $\mathrm{N}(\%)$ & Rerata \\
\hline \multicolumn{4}{|l|}{ Jenis Kelamin } \\
\hline \multirow[t]{2}{*}{ Pria } & DM & $8(14,81)$ & \\
\hline & Tanpa DM & $10(18,52)$ & \\
\hline \multirow[t]{2}{*}{ Wanita } & DM & $19(35,19)$ & \\
\hline & Tanpa DM & $17(31,48)$ & \\
\hline \multirow{3}{*}{$<54$ tahun } & DM dan tanpa DM & & $58,85 \pm 8,69$ \\
\hline & DM & $8(14,81)$ & \\
\hline & Tanpa DM & $4(7,41)$ & \\
\hline \multirow[t]{2}{*}{$\geq 54$ tahun } & DM & $19(35,19)$ & \\
\hline & Tanpa DM & $23(42,59)$ & \\
\hline \multirow[t]{2}{*}{ Kadar Asam Urat } & $\mathrm{DM}$ & & $6.55 \pm 2.25$ \\
\hline & Tanpa DM & & $4.92 \pm 1.30$ \\
\hline
\end{tabular}

Berdasarkan hasil karakteristik subjek penelitian pada tabel 4 menunjukkan bahwa penderita hipertensi dengan DM tipe 2 maupun tanpa DM tipe 2 lebih banyak yang berjenis kelamin wanita, yaitu dengan total sampel 36 pasien $(66,67 \%)$, dibandingkan dengan yang berjenis kelamin pria, dengan total sampel 18 pasien $(33,33 \%)$. Hasil ini serupa dengan penelitian yang dilakukan oleh Sedayu et al (2015), dimana dalam penelitian tersebut menyatakan penderita dengan jenis kelamin wanita lebih banyak menderita hipertensi daripada pria dengan persentase $64,3 \%$.

Untuk karakteristik berdasarkan usia didapatkan rerata seluruh subjek penelitian $( \pm \mathrm{SD})$ adalah $58,85 \pm 8,69$ tahun, usia termuda adalah 37 tahun sedangkan usia tertua adalah 70 tahun. Jumlah penderita terbanyak pada hipertensi dengan dan tanpa DM tipe 2 ditemukan pada kelompok usia $\geq 54$ tahun, yaitu sebanyak 42 pasien (77,78\%). Hasil ini serupa dengan penelitian yang dilakukan oleh Tripenna (2011), dimana dalam penelitian tersebut menjelaskan bahwa proporsi penderita hipertensi terbanyak terdapat pada kelompok usia $\geq 40$ tahun dengan persentase $92 \%$.

Pada karakteristik berdasarkan kadar asam urat didapatkan rerata kadar asam urat pada kelompok hipertensi dengan DM tipe 2 sebesar $6.55 \pm 2.25$, lebih tinggi dibandingkan rerata kadar asam urat pada 
kelompok hipertensi tanpa DM tipe 2 sebesar 4.92 \pm 1.30 , hasil ini sesuai dengan teori yang dikemukakan oleh Verdecchia et al (2000) dan Johnson et al (2003) bahwa DM tipe 2 merupakan salah satu faktor yang dapat meningkatkan kadar asam urat pada penderita hipertensi.

2. Uji Normalitas

Uji normalitas dilakukan untuk mengetahui apakah data terdistribusi normal atau tidak, jika data terdistribusi dengan normal maka akan digunakan uji $\mathrm{T}$ tidak berpasangan sedangkan jika data terdistribusi tidak normal maka akan digunakan uji Mann Whitney. Jumlah sampel pada masing-masing kelompok adalah 27 subjek, maka akan digunakan uji normalitas Shapiro-Wilk.

Sebaran data dikatakan normal apabila nilai p pada uji normalitas ShapiroWilk lebih dari 0,05. Pada table 5 di bawah menunjukkan nilai $\mathrm{p}$ variable asam urat.

Tabel 2. Uji Normalitas Shapiro-Wilk

\begin{tabular}{llcc}
\hline \multirow{2}{*}{ Variabel Terikat } & \multirow{2}{*}{ Variabel Bebas } & \multicolumn{2}{c}{ Shapiro-Wilk } \\
\cline { 3 - 4 } & & Frekuensi & Nilai P \\
\hline Kadar Asam Urat & Hipertensi dg DM (HTDDM) & 27 & 0,141 \\
& Hipertensi tanpa DM (HTTDM) & 27 & 0,176 \\
\hline
\end{tabular}

Dari tabel uji normalitas ShapiroWilk didapatkan hasil bahwa distribusi data kadar asam urat pada kelompok hipertensi dengan DM tipe 2 yaitu $\mathrm{p}>0,05$, yang berarti data terdistribusi dengan normal. Hasil ini sama dengan distribusi data kadar asam urat pada kelompok hipertensi tanpa DM tipe 2 yaitu $p>0,05$, yang berarti data juga terdistribusi dengan normal, jadi untuk uji analisisnya menggunakan uji $\mathrm{T}$ tidak berpasangan (Dahlan, 2010).
3. Uji T Tidak Berpasangan

Uji $\mathrm{T}$ tidak berpasangan dilakukan sesuai dengan hasil uji normalitas, pada uji normalitas masing-masing kelompok didapatkan nilai $\mathrm{p}>0,05$ yang artinya data terdistribusi dengan normal, maka selanjutnya dilakukan uji $\mathrm{T}$ tidak berpasangan.

Hasil uji T tidak berpasangan kadar asam urat ditampilkan dalam tabel berikut:

Tabel 3. Hasil Uji T Tidak Berpasangan

\begin{tabular}{lcccc}
\hline & $\mathrm{n}$ & Rerata \pm s.b. & Perbedaan Rerata (IK95\%) & $p$ \\
\hline DM & 27 & $6.55 \pm 2.25$ & $1.63(0.62-2.64)$ & 0.002 \\
Tanpa DM & 27 & $4.92 \pm 1.30$ & & \\
\hline
\end{tabular}

Tabel 3 diatas menunjukkan hasil uji $\mathrm{T}$ tidak berpasangan dari kadar asam urat dan didapatkan nilai $\mathrm{p}=0,002$, artinya terdapat perbedaan yang signifikan antara rerata kadar asam urat pada penderita hipertensi dengan DM tipe 2 dan tanpa DM tipe 2, karena nilai $\mathrm{p}<0,05$, dimana kadar asam urat pada penderita hipertensi dengan DM tipe 2 lebih tinggi daripada kadar asam urat penderita hipertensi tanpa DM tipe 2 .

Pada penelitian ini menunjukkan bahwa pasien yang menderita hipertensi dengan DM tipe 2 memiliki rerata kadar asam urat lebih tinggi dibandingkan pasien yang menderita hipertensi tanpa DM tipe 2, dimana rerata kadar asam urat pada pasien yang menderita hipertesi dengan DM tipe 2 adalah 6,559 $\pm 2,2560$ dan pada pasien yang menderita hipertensi tanpa DM tipe 2 adalah $4.922 \pm 1.3051$.

Pada penelitian ini didapatkan hasil uji normalitas Shapiro-Wilk $p=0,141$ pada kelompok hipertensi dengan DM tipe 2 dan $\mathrm{p}=0,176$ pada kelompok hipertensi tanpa DM tipe 2, maka dapat disimpulkan datanya terdistribusi dengan normal, sehingga analisa datanya menggunakan uji $\mathrm{T}$ tidak berpasangan. 
Hasil analisa komparatif menggunakan Uji $\mathrm{T}$ tidak berpasangan dalam penelitian ini memberikan signifikansi $\mathrm{p}<0,005$ dengan nilai $\mathrm{p}=0,002$. Hal ini memberikan kesimpulan bahwa terdapat perbedaan rerata kadar asam urat pada penderita hipertensi dengan DM tipe 2 dan tanpa DM tipe 2 di Rumah Sakit Umum Daerah Dr. Sayidiman Magetan. Hasil ini sesuai dengan penelitian sebelumnya yang dilakukan oleh Liong et al (2008), Kodama et al (2009), dan Kramer et al (2009) yang menyatakan bahwa terdapat hubungan yang positif antara kenaikan kadar asam urat dengan faktor resiko berkembangnya DM.

Resistensi insulin sering terjadi pada pasien hipertensi essensial. Insulin mempunyai efek menurunkan ekskresi asam urat serum yang disertai dengan kemampuan untuk menahan natrium. Peningkatan kadar asam urat serum dipengaruhi oleh meningkatnya aktivitas system saraf simpatis yang disebabkan hiperurisemia. Ide bahwa hiperurisemia dapat menjadi indicator resistensi insulin telah dibuktikan pada penelitian longitudinal selama 8 tahun yang telah membuktikan bahwa resistensi insulin berkaitan dengan hiperurisemia. Oleh karena itu hiperurisemia pada penderita hipertensi dapat menjadi petanda adanya resistensi insulin yang dihubungkan langsung dengan peningkatan risiko penyakit kardiovaskuler (Ruilope dan Puig, 2001).

Asam urat telah terbukti berkaitan dengan stres oksidatif dan produksi tumor necrosis factor (TNF)- $\alpha$ yang keduanya berkaitan dengan berkembangnya DM. Selain itu penelitian terbaru pada hewan uji tikus menunjukkan fruktosa yang diinduksi hiperurisemia memegang peranan penting dalam patogenesis sindrom metabolik. Temuan ini mendukung teori yang menyatakan kadar asam urat yang tinggi berperan sebagai prekursor terjadinya DM tipe 2 (Dehghan et al., 2007).

Secarabiologis, asamuratmemainkan peranan penting dalam memburuknya kondisi resistensi insulin pada binatang dengan menghambat bioavailibilitas oksida nitrat. Di sisi lain kondisi hiperinsulinemia sebagai konsekuensi dari resistensi insulin menyebabkan peningkatan konsentrasi asam urat serum dengan cara mengurangi sekresi asam urat dan mengumpulkan substrat untuk produksi asam urat (Kodama et al., 2009).

Kelebihan penelitiaan ini yakni dilakukan pada subjek yang lebih spesifik yakni pada penderita hipertensi, sedangkan pada penelitian sebelumnya hanya menghubungkan kadar asam urat dengan faktor risiko terjadinya DM. Penelitian ini juga mempunyai beberapa kelemahan antara lain adanya beberapa variabel luar yang tidak dikendalikan yaitu indeks masa tubuh, merokok, riwayat pengobatan hipertensi dan konsumsi alkohol dikarenakan keterbatasan data yang tercantum dalam rekam medis pasien. Kelemahan lain dari penelitian ini adalah tidak bisa diketahuinya hubungan sebab akibat dikarenakan metode yang digunakan dalam penelitian ini adalah cross sectional.

\section{SIMPULAN}

Terdapat perbedaan yang bermakna kadar asam urat pada penderita hipertensi dengan DM tipe 2 dan tanpa DM tipe 2.

\section{DAFTAR PUSTAKA}

Abreu E., Fonseca MJ., Santos AC., 2011. Association between Hyperuricemia and Insulin Resistance. Acta Med Port, 24 (Suppl 2):565-74

Campbell N.R.C et al., 2011. Hypertension in people with type 2 diabetes. Canadian Family Physician, ;57(9):997-1002.

Dahlan M.S., 2010. Besar Sampel Dan Cara Pengambilan Sampel Dalam Penelitian Kedokteran Dan Kesehatan Edisi Tiga. Jakarta: Salemba Medika.

Dehghan A, van Hoek, M, Sijbrands EJG, Hofman A, and Witteman JCM , 2007. High serum uric acid as a novel risk factor for type 2 diabetes mellitus. Diabetes Care;31(2):3612 
Dinas kesehatan Provinsi Jawa Timur. 2013. Profil kesehatan Provinsi Jawa Timur 2012, pp 1-93.

Johnson R.J, Kang DH, Feig D, Kivlighn S, Kanellis J, Watanabe S, Tuttle KR, Rodriguez-Iturbe B, et al., 2003. Is there a pathogenetic role for uric acid in hypertension and cardiovascular and renal disease? Hypertension, 41:118390.

Kodama S, Saito K, Yachi Y, Asumi M, Sugawara A, Totsuka K, Saito A, Sone H., 2009. Association Between Serum Uric Acid and Development of Type 2 Diabetes. Diabetes Care, 32(9): 1737-42.

Kremer C.K, von Mühlen D, Jassal SK, BarrettConnor E., 2009. Serum Uric Acid Levels Improve Prediction of Incident Type 2 Diabetes in Individuals With Impaired Fasting Glucose. Diabetes care, 32(7):12723

Liong C.K Chen MF, Hsu HC, Chang WT, Su TC, Lee YT, Hu FB., 2008. Plasma Uric Acid and the Risk of Type 2 Diabetes in a Chinese Community. Clin Chem., 54(2):310-6..

Ruilope L.M., Puig., 2001. Kidney function, a sensitive predictor of cardiovascular risk. Am J Hypertension, 14 (S3): 213S-7S.

Sedayu B., Azmi S., Rahmatini., 2015. Karakteristik Pasien Hipertensi di Bangsal Rawat Inap SMF Penyakit Dalam RSUP DR. M. Djamil Padang Tahun 2013. Jurnal Kesehatan Andalas. 4:65-9
Taniguchi Y, Hayashi T, Tsumura K, Endo G, Fujii

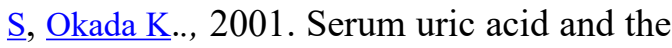
risk for hypertension and type 2 diabetes in Japanese men: the Osaka health survey. $J$ Hypertension, 19(7): 1209-15

Verdecchia P, Schillaci G, Reboldi G, Santeusanio F, Porcellati C, Brunetti P., 2000. Relation between Serum Uric Acid and Risk of Cardiovascular Disease in Essential Hypertension. Hypertension.;36:1072-78

Weir C.J, Muir SW, Walters MR, Lees KR., 2003. Serum Urate as an Independent Predictor of Poor Outcome and Future Vascular Events After Acute Stroke. Stroke;34(8):1951-6

Wild S, Roglic G, Green A, Sicree R, and King H, 2004. Global prevalence of diabetes: Estimates for the year 2000 and projections for 2030. Diabetes Care; 27: 1047-53.

World Health Organization. 2013. World Health Day. A Global Brief On Hypertension. Geneva: 1-40

Yugiantoro M., 2014. Pendekatan Klinis Hipertensi. In: Setiati dkk (ed). Buku Ajar Ilmu Penyakit Dalam Jilid II Edisi VI. Jakarta: FKUI, 2259-83. 